\title{
Article \\ The Impact of Diet on Urinary Risk Factors for Cystine Stone Formation
}

\author{
Roswitha Siener ${ }^{1, *}$, Norman Bitterlich ${ }^{2}$, Hubert Birwé ${ }^{1}$ and Albrecht Hesse ${ }^{1}$ \\ 1 Department of Urology, University Stone Center, University Hospital Bonn, 53127 Bonn, Germany; \\ hubert.birwe@hebgmbh.de (H.B.); albrecht-hesse@web.de (A.H.) \\ 2 Department of Biostatistics, Medicine and Service Ltd., 09117 Chemnitz, Germany; \\ bitterlich@medizinservice-sachsen.de \\ * Correspondence: roswitha.siener@ukbonn.de; Tel.: +49-228-287-19034
}

\section{check for}

updates

Citation: Siener, R.; Bitterlich, N.; Birwé, H.; Hesse, A. The Impact of Diet on Urinary Risk Factors for Cystine Stone Formation. Nutrients 2021, 13, 528. https://doi.org/ $10.3390 /$ nu13020528

Academic Editor: Adamasco Cupisti Received: 30 December 2020

Accepted: 3 February 2021

Published: 6 February 2021

Publisher's Note: MDPI stays neutral with regard to jurisdictional claims in published maps and institutional affiliations.

Copyright: (c) 2021 by the authors. Licensee MDPI, Basel, Switzerland. This article is an open access article distributed under the terms and conditions of the Creative Commons Attribution (CC BY) license (https:// creativecommons.org/licenses/by/ $4.0 /)$.

\begin{abstract}
Despite the importance of dietary management of cystinuria, data on the contribution of diet to urinary risk factors for cystine stone formation are limited. Studies on the physiological effects of diet on urinary cystine and cysteine excretion are lacking. Accordingly, 10 healthy men received three standardized diets for a period of five days each and collected daily $24 \mathrm{~h}$ urine. The Western-type diet (WD; $95 \mathrm{~g} /$ day protein) corresponded to usual dietary habits, whereas the mixed $\operatorname{diet}(\mathrm{MD} ; 65 \mathrm{~g} /$ day protein) and lacto-ovo-vegetarian diet (VD; $65 \mathrm{~g} /$ day protein) were calculated according to dietary reference intakes. With intake of the VD, urinary cystine and cysteine excretion decreased by 22 and $15 \%$, respectively, compared to the WD, although the differences were not statistically significant. Urine $\mathrm{pH}$ was significantly highest on the VD. Regression analysis showed that urinary phosphate was significantly associated with cystine excretion, while urinary sulfate was a predictor of cysteine excretion. Neither urinary cystine nor cysteine excretion was affected by dietary sodium intake. A lacto-ovo-vegetarian diet is particularly suitable for the dietary treatment of cystinuria, since the additional alkali load may reduce the amount of required alkalizing agents.
\end{abstract}

Keywords: dietary treatment; dietary protein; sodium chloride; methionine; phosphorus; urinary $\mathrm{pH}$; urinary phosphate excretion; urinary cystine excretion; cystinuria; urolithiasis

\section{Introduction}

Cystinuria accounts for less than $1 \%$ of urinary stones in adults but up to $8 \%$ of urolithiasis in children and adolescents [1,2]. Cystinuria is a genetic disorder of the proximal tubular reabsorption of cystine and the dibasic amino acids arginine, ornithine, and lysine [3-6]. The hyperexcretion and poor solubility of cystine in urine can lead to crystallization and a lifetime risk of recurrent stone formation. The subsequent need for multiple stone removal procedures may contribute to impaired renal function [7]. Cystinuria requires consistent lifelong therapy. For patients who fail to respond to dietary measures and alkali therapy, pharmacotherapy with the currently available chelating thiol drugs, alphamercaptopropionyl glycine and D-penicillamine, is indicated. However, a variety of side effects, such as alterations in taste perception, mucocutaneous lesions, immune-mediated diseases, hematological reactions, proteinuria, and nephrotic syndrome, may necessitate discontinuation of medical therapy [8].

Dietary treatment plays a pivotal role in the management of cystine stone formation. The primary treatment strategy for cystine stone disease is focused on reducing $24 \mathrm{~h}$ urinary cystine excretion and concentration and increasing urinary cystine solubility [9-11]. High fluid intake to decrease urinary cystine concentration is the most important measure to prevent recurrences in patients with cystinuria. Furthermore, restricting dietary protein intake is recommended for two reasons. First, reducing the dietary intake of cystine and methionine is considered to decrease urinary cystine excretion [12]. Second, ingesting a high-protein diet with small amounts of plant foods may reduce urine $\mathrm{pH}$ and counteract alkalinization 
therapy due to the high content of the sulfur-containing amino acid methionine $[13,14]$. In addition, restricting dietary sodium to less than $2.3 \mathrm{~g} /$ day is recommended for patients with cystinuria based on the assumption that reduced intake of dietary sodium will lower urinary cystine excretion [15-17]. However, neither of these dietary measures has been demonstrated to reduce cystine stone formation in clinical trials.

A usual Western diet may promote cystine stone formation, as methionine is contained in substantial quantities in meat, sausages, fish, eggs, and dairy products [9]. Cystine stone patients are therefore advised to maintain a balanced mixed diet with moderate animal protein content $[9,18]$. A vegetarian diet theoretically may further reduce urinary cystine excretion and increase cystine solubility by increasing urine $\mathrm{pH}$. However, there has been little investigation on the contribution of dietary modifications to the urinary risk profile of cystine stone formation. Studies on the physiological effects of diet on urinary cystine and cysteine excretion are lacking. The aim of this trial was to evaluate the impact of a Western-type, a balanced mixed, and a lacto-ovo-vegetarian diet on urinary risk factors for cystine stone formation in healthy subjects under controlled standardized conditions.

\section{Materials and Methods}

\subsection{Study Design}

Ten healthy men were enrolled in this study. Each participant had normal findings on clinical examination and Combur-9 test (Roche Diagnostics). The individuals took no dietary supplements or medications during the study. The subjects received three diets for five days each. The standardized diets were a Western-type diet (WD), a balanced mixed $\operatorname{diet}(\mathrm{MD})$, and a balanced lacto-ovo-vegetarian diet (VD). The composition of the diets is presented in Table 1.

Table 1. Composition of the standardized Western-type, balanced mixed, and lacto-ovovegetarian diet.

\begin{tabular}{cccc}
\hline & $\begin{array}{c}\text { Western-Type } \\
\text { Diet }\end{array}$ & $\begin{array}{c}\text { Mixed } \\
\text { Diet }\end{array}$ & $\begin{array}{c}\text { Vegetarian } \\
\text { Diet }\end{array}$ \\
\hline Energy (kcal/day/MJ/day) & $3590 / 15.01$ & $2544 / 10.63$ & $2600 / 10.88$ \\
Total protein (g/day) & 95 & 65 & 65 \\
Animal protein (g/day) & 56 & 37 & 28 \\
Plant protein (g/day) & 39 & 28 & 37 \\
Protein (g/kg BW/day) & 1.2 & 0.8 & 0.8 \\
Carbohydrates (g/day) & 380 & 370 & 386 \\
Fat (g/day) & 132 & 82 & 84 \\
Methionine (mg/day) & 2290 & 1445 & 1122 \\
Cystine (mg/day) & 1543 & 918 & 714 \\
Phosphorus (mg/day) & 1840 & 1283 & 1457 \\
Calcium (mg/day) & 876 & 768 & 787 \\
Potassium (mg/day) & 3560 & 3314 & 6584 \\
Sodium (mg/day) 1 & 4044 & 3351 & 2339 \\
Fluid (mL/day) & 1500 & 2500 & 2500 \\
\hline
\end{tabular}

Abbreviations: BW, body weight; MJ, megajoules. ${ }^{1}$ Calculated from urinary excretion.

The WD corresponded to usual eating patterns. Typical for a Western diet is a high intake of protein, methionine, cystine, and phosphorus. In contrast, the composition of the balanced MD and VD corresponded to the dietary reference intakes of the German, Austrian, and Swiss Societies of Nutrition [19]. The MD and VD contained similar amounts of the main nutrients fat, carbohydrates, and total protein. The daily fluid intake through beverages was $1.5 \mathrm{~L}$ on the $\mathrm{WD}$ and $2.5 \mathrm{~L}$ on the MD and VD. Dietary sodium intake was assessed by urinary excretion [20-22]. The composition of each standardized diet was estimated using PRODI version 5.3 (WVG, Stuttgart, Germany). The standardized dietary regimen, i.e., consistent daily intake of prescribed foods and fluids, leads to a steady state of metabolism so that consistent urinary values are achieved [23]. Daily $24 \mathrm{~h}$ urine samples 
were collected and analyzed for urinary parameters to ensure adjustment to each diet. The Ethics Committee of the Medical Faculty of the University of Bonn (01889) approved the study and informed consent was obtained.

\subsection{Analytical Procedures}

Urine volume, density, $\mathrm{pH}$ (potentiometry), urinary sodium, calcium and potassium (flame emission spectrophotometry), chloride (coulomb metric titration), ammonium (ion selective electrode), inorganic phosphate (phosphate molybdate reaction), inorganic sulfate (nephelometry), and creatinine (Jaffé reaction) were analyzed. Laboratory quality certification was available for each parameter. Urinary cysteine and cystine were determined using reversed-phase high-performance liquid chromatography (HPLC) with pre-column derivatization of amino acids [24]. The ion activity product of cystine was determined as described by Tiselius [25].

\subsection{Statistical Analysis}

Nonparametric Friedman one-way repeated measure analysis of variance (ANOVA) by ranks was used to explore the effects of different diets on urinary parameters. The HolmBonferroni method was used to adjust for multiple pairwise testing of diets. Comparisons of outcome variables by diet were completed with generalized linear models with an identity link and a per-person random effect. Spearman's rank correlation coefficient (R) was applied to assess the direction and strength of the linear relationship between two variables of each diet. The last day of each diet served as control, since steady-state conditions were then attained. The significance level was considered as $p<0.05$. All statistical tests were two-sided. Statistical analysis was performed using SPSS ${ }^{\circledR}$ for Windows version 25.0 (IBM, Armonk, New York, NY, USA).

\section{Results}

A total of 10 men aged 21-32 years (mean \pm SD: $27.7 \pm 3.1$ years) were included in the study and completed all visits. The mean body height, weight, and body mass index (BMI) of the participants was $178.7 \pm 4.5 \mathrm{~cm}, 78.9 \pm 11.7 \mathrm{~kg}$, and $24.7 \pm 3.7 \mathrm{~kg} / \mathrm{m}^{2}$, respectively.

Table 2 presents the urinary risk profile on the last day of the WD, MD, and VD. Both urinary cystine and cysteine excretion tended to be lower on the VD compared to the WD, although the differences were not statistically significant. Urinary cystine excretion was 131,97 , and $103 \mu \mathrm{mol} / 24 \mathrm{~h}$ on the WD, MD, and VD, respectively. The urinary cystineto-cysteine ratio did not change throughout the study. Urinary cystine concentration was significantly lower on the MD and VD compared to the WD due to significant differences in urinary volume, which is also reflected by urine density.

Urine $\mathrm{pH}$ was significantly lowest on the WD and highest on the VD. Urine $\mathrm{pH}$ was at the upper physiological limit of 6.8 on the lacto-ovo-vegetarian diet. Urinary ammonium excretion was inversely related to urinary $\mathrm{pH}$ and potassium excretion on each diet. Urinary sodium and chloride excretion differed significantly between diets and were highest on the WD, moderate on the MD, and lowest on the VD. Urinary sulfate excretion was significantly lower on the MD and VD than the WD. Urinary phosphate excretion was significantly higher on the WD compared to the VD. Urinary calcium excretion was significantly highest on the WD and lowest on the VD. Urinary creatinine excretion did not differ between the study phases. The ion activity product of cystine was significantly lower on the MD and VD than on the WD.

Figure $1 \mathrm{a}, \mathrm{b}$ shows the individual course of $24 \mathrm{~h}$ urinary parameters of participants on the different diets. Compared to the WD, the VD resulted in decreased urinary cystine excretion in 9 of the 10 individuals (Figure 1a). In all 10 participants, urine pH was highest on the VD (Figure 1b). A sensitivity analysis without the outlier confirmed the results. 
Table 2. Urinary parameters on the standardized Western-type, balanced mixed, and lacto-ovo-vegetarian diet $(n=10)$.

\begin{tabular}{|c|c|c|c|c|c|c|c|}
\hline & $\begin{array}{c}\text { Western-Type } \\
\text { Diet }\end{array}$ & $\begin{array}{c}\text { Mixed } \\
\text { Diet }\end{array}$ & $\begin{array}{c}\text { Vegetarian } \\
\text { Diet }\end{array}$ & $\begin{array}{l}\text { WD vs. } \\
\text { MD }\end{array}$ & $\begin{array}{l}\text { WD vs. } \\
\text { VD }\end{array}$ & $\begin{array}{l}\text { MD vs. } \\
\text { VD }\end{array}$ & $\begin{array}{c}\text { Friedman } \\
\text { Test }\end{array}$ \\
\hline & Mean \pm SD & Mean \pm SD & Mean \pm SD & $p$ Value & $p$ Value & $p$ Value & $p$ Value \\
\hline Volume (L/24 h) & $1.48 \pm 0.38$ & $2.30 \pm 0.39$ & $2.45 \pm 0.76$ & 0.002 & 0.006 & 0.557 & 0.001 \\
\hline Density $\left(\mathrm{g} / \mathrm{cm}^{3}\right)$ & $1.015 \pm 0.005$ & $1.007 \pm 0.002$ & $1.007 \pm 0.003$ & 0.002 & 0.002 & 0.254 & $<0.001$ \\
\hline $\mathrm{pH}$ & $5.95 \pm 0.34$ & $6.51 \pm 0.22$ & $6.80 \pm 0.21$ & 0.002 & 0.002 & 0.004 & $<0.001$ \\
\hline Cystine ( $\mu \mathrm{mol} / 24 \mathrm{~h})$ & $130.9 \pm 35.0$ & $96.8 \pm 33.2$ & $102.5 \pm 56.3$ & 0.131 & 0.064 & 0.695 & 0.046 \\
\hline Cystine $(\mu \mathrm{mol} / \mathrm{L})$ & $96.4 \pm 44.5$ & $43.6 \pm 18.0$ & $46.1 \pm 28.2$ & 0.004 & 0.002 & 0.695 & $<0.001$ \\
\hline Cysteine ( $\mu \mathrm{mol} / 24 \mathrm{~h})$ & $72.5 \pm 25.5$ & $66.8 \pm 39.2$ & $61.5 \pm 43.3$ & 0.105 & 0.084 & 0.131 & 0.006 \\
\hline Cystine-to-cysteine-ratio & $1.90 \pm 0.55$ & $1.94 \pm 1.11$ & $2.07 \pm 0.98$ & 0.922 & 1.000 & 0.922 & 0.974 \\
\hline Sodium $(\mathrm{mmol} / 24 \mathrm{~h})$ & $176 \pm 40$ & $146 \pm 13$ & $102 \pm 48$ & 0.020 & 0.006 & 0.014 & 0.001 \\
\hline Chloride (mmol/24 h) & $169 \pm 39$ & $139 \pm 17$ & $106 \pm 43$ & 0.049 & 0.010 & 0.020 & 0.046 \\
\hline Potassium (mmol/24 h) & $60 \pm 11$ & $77 \pm 16$ & $110 \pm 20$ & 0.006 & 0.002 & 0.002 & $<0.001$ \\
\hline Calcium (mmol/24 h) & $4.48 \pm 1.22$ & $3.09 \pm 1.39$ & $2.46 \pm 1.33$ & 0.002 & 0.002 & 0.004 & $<0.001$ \\
\hline Ammonium (mmol/24 h) & $38.7 \pm 5.1$ & $25.6 \pm 6.4$ & $18.7 \pm 5.9$ & 0.002 & 0.002 & 0.002 & $<0.001$ \\
\hline Phosphate (mmol/24 h) & $35.4 \pm 5.5$ & $29.4 \pm 3.5$ & $25.2 \pm 6.3$ & 0.027 & 0.004 & 0.131 & 0.006 \\
\hline Sulfate $(\mathrm{mmol} / 24 \mathrm{~h})$ & $22.5 \pm 3.1$ & $18.1 \pm 1.9$ & $16.1 \pm 3.7$ & 0.002 & 0.002 & 0.264 & 0.002 \\
\hline Creatinine (mmol/24 h) & $16.88 \pm 1.97$ & $15.32 \pm 1.31$ & $13.77 \pm 3.16$ & 0.020 & 0.064 & 0.105 & 0.135 \\
\hline AP Cystine $\left(\times 10^{-22}\right)$ & $3.89 \pm 2.01$ & $1.42 \pm 0.73$ & $1.27 \pm 0.94$ & 0.002 & 0.002 & 0.557 & $<0.001$ \\
\hline
\end{tabular}

Abbreviations: AP, ion activity product; $\mathrm{WD}$, Western-type diet; $\mathrm{MD}$, balanced mixed diet; $\mathrm{VD}$, balanced lacto-ovo-vegetarian diet; $\mathrm{SD}$, standard deviation.

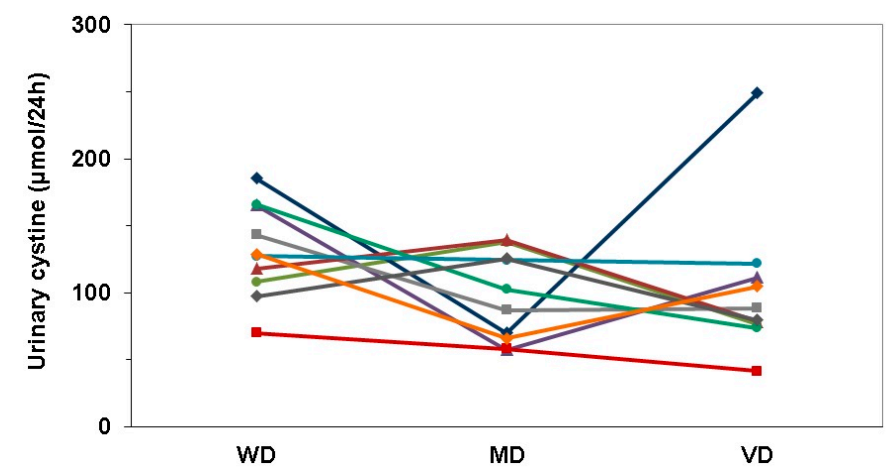

(a)

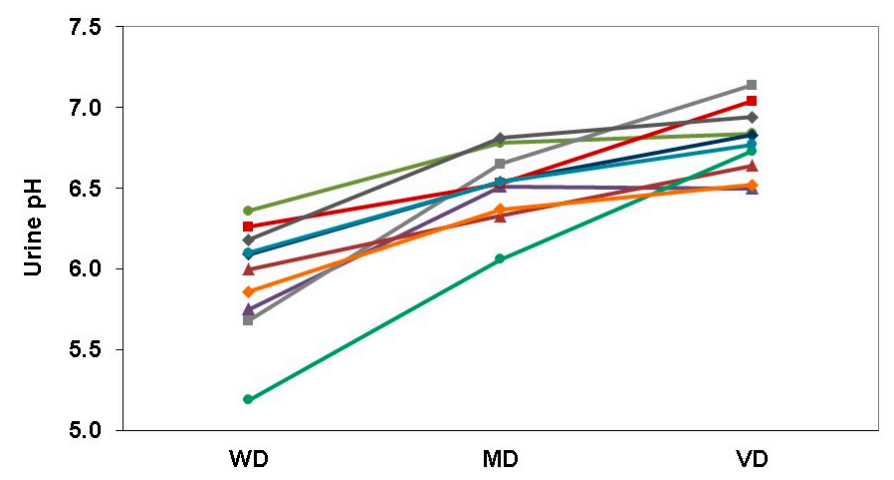

(b)

Figure 1. Individual course of $24 \mathrm{~h}$ urinary parameters of all participants on the different diets: (a) Urinary cystine excretion; (b) Urine pH. Abbreviations: WD, Western-type diet; MD, balanced mixed diet; VD, balanced lacto-ovo-vegetarian diet.

Figure $2 \mathrm{a}-\mathrm{c}$ demonstrates the association of $24 \mathrm{~h}$ urinary cystine excretion and suggested risk factors for cystine stone formation. Urinary phosphate was positively correlated with urinary cystine excretion on the WD and VD (WD: $\mathrm{R}=0.709, p=0.022 ; \mathrm{MD}: \mathrm{R}=0.261$, $p=0.467$; VD: $\mathrm{R}=0.648, p=0.043$ ) (Figure 2a), while urinary cystine excretion was neither associated with urinary sulfate (WD: $\mathrm{R}=0.139, p=0.701$; $\mathrm{MD}: \mathrm{R}=0.418, p=0.229$; VD: $\mathrm{R}=-0.006, p=0.987$ ) (Figure $2 \mathrm{~b}$ ) nor with urinary sodium excretion (WD: $\mathrm{R}=-0.006$, $p=0.987 ; \mathrm{MD}: \mathrm{R}=-0.188, p=0.603$; VD: $\mathrm{R}=0.176, p=0.627$ ) (Figure 2c).

Additional analysis revealed that urinary calcium excretion was neither correlated with urinary cystine (WD: $\mathrm{R}=0.588, p=0.074 ; \mathrm{MD}: \mathrm{R}=-0.248, p=0.489$; $\mathrm{VD}: \mathrm{R}=0.345$, $p=0.328$ ) nor with urinary phosphate excretion (WD: $\mathrm{R}=0.212, p=0.556$; $\mathrm{MD}: \mathrm{R}=-0.297$, $p=0.405$; VD: $\mathrm{R}=0.418, p=0.229)$. Moreover, urinary cystine excretion was not associated with urine $\mathrm{pH}$ on the $\mathrm{MD}$ and $\mathrm{VD}$ (WD: $\mathrm{R}=-0.745, p=0.013$; $\mathrm{MD}: \mathrm{R}=0.231, p=0.521$; $\mathrm{VD}$ : $\mathrm{R}=-0.309, p=0.385$ ).

Univariate regression analysis confirmed that neither urinary sodium nor sulfate excretion was a predictor of urinary cystine excretion, but phosphate excretion was (Table 3). 


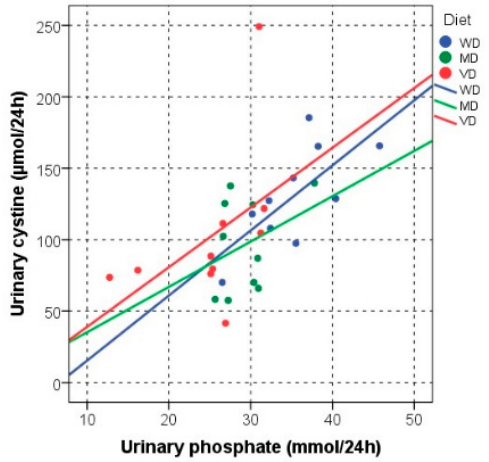

(a)

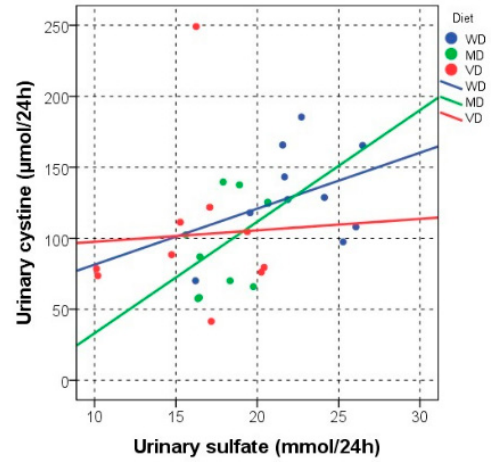

(b)

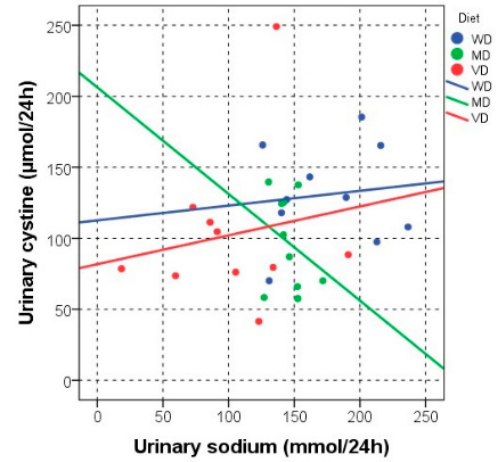

(c)

Figure 2. Association of $24 \mathrm{~h}$ urinary cystine excretion and suggested urinary risk factors for cystine stone formation (a) Urinary phosphate excretion; (b) Urinary sulfate excretion; (c) Urinary sodium excretion. Abbreviations: WD, Western-type diet; MD, balanced mixed diet; VD, balanced lacto-ovo-vegetarian diet.

Table 3. Univariate associations of different diets and $24 \mathrm{~h}$ urinary parameters with urinary cystine excretion.

\begin{tabular}{cccc}
\hline Cystine & Coefficient B & $\mathbf{9 5 \%}$ CI & $p$ Value \\
\hline Diet WD & (reference) & & \\
Diet MD & -13.91 & $-50.33-22.52$ & 0.454 \\
Diet VD & 9.40 & $-35.65-54.46$ & 0.682 \\
Sodium $(70 \mathrm{mmol} / 24 \mathrm{~h})$ & 0.04 & $-0.41-0.49$ & 0.853 \\
Sulfate $(6 \mathrm{mmol} / 24 \mathrm{~h})$ & -2.13 & $-8.48-4.22$ & 0.510 \\
Phosphate $(10 \mathrm{mmol} / 24 \mathrm{~h})$ & 4.77 & $1.71-7.83$ & 0.002
\end{tabular}

Abbreviations: WD, Western-type diet; MD, balanced mixed diet; $\mathrm{VD}$, balanced lacto-ovo-vegetarian diet; $\mathrm{CI}$, confidence interval. The $p$ values are from generalized models with a per-person random effect. The Coefficient $\mathrm{B}$ is the estimated difference in urinary cystine excretion per difference in univariate predictor.

In addition, univariate regression analysis revealed that neither urinary sodium nor phosphate excretion was a predictor of urinary cysteine excretion, but sulfate excretion was (Table 4).

Table 4. Univariate associations of different diets and $24 \mathrm{~h}$ urinary parameters with urinary cysteine excretion.

\begin{tabular}{cccc}
\hline Cysteine & Coefficient B & $\mathbf{9 5 \% ~ C I ~}$ & $p$ Value \\
\hline Diet WD & (reference) & & \\
Diet MD & 21.98 & $-9.10-53.08$ & 0.166 \\
Diet VD & 32.17 & $-6.29-70.64$ & 0.101 \\
Sodium $(70 \mathrm{mmol} / 24 \mathrm{~h})$ & 0.22 & $-0.27-0.49$ & 0.569 \\
Sulfate $(6 \mathrm{mmol} / 24 \mathrm{~h})$ & 5.90 & $0.48-11.32$ & 0.033 \\
Phosphate $(10 \mathrm{mmol} / 24 \mathrm{~h})$ & -0.31 & $-2.92-2.30$ & 0.817 \\
\hline
\end{tabular}

Abbreviations: WD, Western-type diet; MD, balanced mixed diet; VD, balanced lacto-ovo-vegetarian diet; $\mathrm{CI}$, confidence interval. The $p$ values are from generalized models with a per-person random effect. The Coefficient $\mathrm{B}$ is the estimated difference in urinary cysteine excretion per difference in univariate predictor.

\section{Discussion}

The dietary management of cystine stone formation comprises high fluid intake, urine alkalinization, and attempts reducing urinary cystine excretion by limiting protein and sodium intake. However, studies on the contribution of diet to the urinary risk profile for cystine stone formation are limited. In the present study in healthy subjects, $24 \mathrm{~h}$ cystine excretion was highest with intake of the Western-type diet (WD). The dietary protein restriction of $32 \%$ on the balanced MD and VD led to a reduction in urinary cystine excretion of $26 \%$ (WD vs. MD) and 22\% (WD vs. VD). Due to the high variability of urinary cystine excretion, the differences in this parameter were not statistically significant. 
A study conducted by Rodman et al. [12] of seven patients with cystinuria aged 17 to 35 years reported a significant decline in the mean urinary excretion of $1 / 2$-cystine by $20 \%$ from $6.13 \mathrm{mmol} / 24 \mathrm{~h}$ on a high-protein diet to $4.89 \mathrm{mmol} / 24 \mathrm{~h}$ on a low-protein diet. The mean total protein intake on the low-protein diet was $54 \mathrm{~g}$ /day with $27 \mathrm{~g}$ from plant sources, while the protein-rich diet contained a minimum of $140 \mathrm{~g} /$ day of total protein with only $40 \mathrm{~g}$ from plant sources. However, the diets chosen for that study were relatively extreme. The protein content of the protein-rich diet was higher than what the majority of people customarily eat, and with the low-protein diet, it was difficult to meet the recommended dietary requirements for most adults [12]. A previous study of a 7-year-old girl with cystinuria found that severe restriction of protein to $20 \mathrm{~g}$ per day compared with $117 \mathrm{~g} /$ day reduced urinary cystine excretion by 31\% [26].

A diet low in cystine and its precursor methionine is assumed to diminish urinary cystine excretion. The essential amino acid methionine is abundant in animal protein with high biological value such as meat, sausages, fish, eggs, and cheese. In comparison to animal protein, plant-based protein generally has lower cystine and methionine content. Surprisingly, in the present study of healthy subjects, $24 \mathrm{~h}$ sulfate excretion did not predict the outcome of urinary cystine excretion. Urinary sulfate excretion is considered as a biomarker of sulfur-containing amino acids, as sulfate is generated by the metabolism of methionine and cysteine [14,21]. From the present findings, it is concluded that the amount of dietary sulfur-containing amino acids was not the major determinant of urinary cystine excretion.

Univariate regression analysis revealed that urinary phosphate, instead of sulfate excretion, was a predictor of urinary cystine excretion. Under physiological conditions, $24 \mathrm{~h}$ urinary phosphate excretion has been regarded as a reliable marker of net gastrointestinal phosphate absorption, which in turn is related to the type and quantity of phosphorus present in the diet [27]. Morimoto et al. [28] reported that $24 \mathrm{~h}$ urinary phosphate excretion can be applied to estimate the amount of dietary phosphorus intake in healthy subjects, and that it may even be superior to estimates using weighed dietary records. Trautvetter et al. [29] confirmed that $24 \mathrm{~h}$ urine collection should be used to assess dietary phosphorus intake. Although the dietary phosphorus content of the VD was between the other diets, urinary phosphate excretion was significantly lower only on the VD compared to the WD. Phosphorus from organic phosphates is part of the animal and plant protein present in meat, sausages, milk and milk products, bread, and nuts. While phosphorus from plant sources is less digestible and hence less available for absorption than phosphorus from animal sources, processed foods containing inorganic phosphates as additives have the maximum potential bioavailability $[27,30]$. Unfortunately, we were not able to identify the amount of added inorganic phosphorus in the different diets; however, it is suggested that processed foods included in the Western-type diet, such as sausages and soft drinks, contain highly bioavailable phosphate additives [31]. A recent study on the effect of thiol drugs on patients with cystinuria demonstrated that $24 \mathrm{~h}$ urinary phosphate excretion was a predictor of cystine-binding capacity [32]. Whereas in a non-enhanced mixed diet, the digestible phosphorus is closely correlated with total protein content [30], the exact mechanism by which dietary phosphorus intake is associated with urinary cystine excretion is not clear.

In this study of healthy subjects, $24 \mathrm{~h}$ urinary sulfate excretion was a predictor of urinary cysteine excretion. In food protein, cysteine exists mainly in the form of cystine because cysteine is rapidly oxidized to cystine in normoxic conditions [33]. Cysteine can usually be synthesized in the body under normal physiological conditions if a sufficient quantity of methionine is available. The significant association of urinary sulfate excretion with urinary cysteine excretion suggests that urinary cysteine is derived mainly from dietary methionine and cystine. In urine, cystine and cysteine are in a redox state [24]. Reductive substances cleave the disulfide bond of cystine, leading to the conversion of cystine to its more soluble monomer cysteine. For monitoring of therapy, the differentiation between cystine and cysteine is essential, and it can only be achieved by using high- 
performance liquid chromatography (HPLC)-based analysis [24]. In the present study, no significant differences in the cystine-to-cysteine ratio were observed between the diets.

Since diets low in protein have demonstrated no clear benefit and can lead to diminished intake of essential amino acids, total protein intake should not be restricted below the dietary reference value of $0.8-1.0 \mathrm{~g}$ protein per $\mathrm{kg}$ ideal body weight per day for adults. In the present study, the total protein content of the balanced mixed diet and the lacto-ovo-vegetarian diet of $0.8 \mathrm{~g}$ per $\mathrm{kg}$ body weight per day meets the recommended intake and is intended for long-term use.

Restricting dietary sodium intake has been suggested to be an effective measure to reduce urinary cystine excretion in patients with cystinuria [15-17,34,35]. A study of four patients with cystinuria reported that urinary cystine excretion can be expected to decrease by about $650 \mu \mathrm{mol}$ per $24 \mathrm{~h}$ if dietary sodium intake is reduced by $150 \mathrm{mmol}$ per day [15]. Norman and Manette [16] confirmed the findings in five adult patients with recurrent cystine stone formation. Restricting dietary sodium intake from 4200 to $2000 \mathrm{mg} /$ day resulted in a significant decline in mean cystine excretion by $51 \%$. In five children with cystinuria, Rodriguez et al. [35] showed that a low-salt diet was effective in reducing urinary cystine concentration. A study of 79 samples of $24 \mathrm{~h}$ urine from 69 patients with cystine stones demonstrated a strong association of urinary sodium with cystine excretion [17].

The mechanism that determines the association of increased urinary cystine excretion with increased sodium intake in cystinuric patients is unknown, as the reabsorption of cystine in the proximal tubule is sodium-independent $[17,36,37]$. It was speculated that high sodium intake would increase the intracellular neutral amino acid and sodium load, which might slow the apical reabsorption of cystine $[11,36,37]$. The present study, with normal subjects, was not able to confirm the previous findings, and thus rejected the hypothesis of an effect of dietary sodium intake, as judged by urinary excretion, on urinary cystine excretion. Although no association between dietary sodium intake and urinary cystine excretion was observed in the present study, restricting dietary sodium to $2300 \mathrm{mg} /$ day (100 mmol/day) or $6 \mathrm{~g} /$ day of sodium chloride is recommended as part of a healthy diet, even if its potential benefit in preventing cystine stones is not supported by clinical trials [11]. Strict dietary sodium restriction to below $2 \mathrm{~g}$ per day is not necessary, and is difficult to achieve and maintain.

Urine alkalinization is an important measure to increase solubility of cystine in urine. The upper limit of solubility of cystine at a physiological urine $\mathrm{pH}$ range between 5 and 7 is approximately $300-400 \mathrm{mg} / \mathrm{L}(1.3-1.7 \mathrm{mmol} / \mathrm{L})$, but cystine solubility increases markedly when urine $\mathrm{pH}$ is raised to above 7.5 [26]. Urine alkalinization to reach the therapeutic target of $\mathrm{pH} 7.5$ to 8.0 is a cornerstone of treatment of all patients with cystinuria and is recommended as a basic measure [10,11]. However, large doses of alkalizing agents are required to achieve the recommended urine $\mathrm{pH}$ range and gastrointestinal side effects can limit compliance with treatment [38-40]. Therefore, it is recommended to support pharmacological therapy for urine alkalinization with dietary measures.

A high-protein diet that is not compensated by higher alkali ingestion from fruits and vegetables increases the endogenous acid load [13]. Dietary intake of high amounts of the sulfur-containing amino acid methionine may reduce urine $\mathrm{pH}$ and counteract alkalinization therapy $[13,14]$. In the present study, the comparatively low urine $\mathrm{pH}$ and high urinary phosphate and sulfate excretion with the Western-type diet were mainly attributed to the acidifying effect of phosphoproteins and the sulfur-containing amino acids methionine and cystine, which are present in a higher proportion in animal protein sources than in foods derived from plants [14]. The high endogenous acid load with the WD was associated with a low urine $\mathrm{pH}$, which could promote cystine stone formation. Reducing total protein intake on the MD and VD decreased hydrogen ion excretion and significantly increased urine $\mathrm{pH}$, with concomitant reduction in urinary ammonium excretion. A vegetarian diet is particularly suitable for the dietary treatment of cystine stone disease, since the alkaline 
load from fruits and vegetables should reduce the amount of alkalizing agents required to achieve urine alkalinization at $\mathrm{pH}$ greater than 7.5.

A high urine volume is the most important factor in reducing urinary cystine concentration and preventing cystine stone formation. To maintain cystine concentration below the solubility limit of $1.3 \mathrm{mmol} / \mathrm{L}(300 \mathrm{mg} / \mathrm{L})$ at $\mathrm{pH} 6$ in adult patients with cystinuria, urine volume of at least $3.0 \mathrm{~L}$ per $24 \mathrm{~h}$ should be achieved $[9,11,25,41-44]$. To ensure adequate hydration, a urine specific gravity of less than 1.005 has been recommended [11,45]. Hydration has been found to prevent recurrent stone formation in as many as two-thirds of patients with cystinuria [46]. In a previous study of 27 adult patients with cystinuria, maintaining a daily urine volume of more than $3.0 \mathrm{~L}$ for a mean of 11.6 years was associated with a significant reduction in new stone formation [41]. While consuming the Western-type diet, 24-h urine volume was far below the therapeutic recommendations for cystine stone patients. Due to the higher fluid intake, mean urine volume was significantly higher on the MD $(2.30 \mathrm{~L} / 24 \mathrm{~h})$ and the $\operatorname{VD}(2.45 \mathrm{~L} / 24 \mathrm{~h})$, which was also documented by urine density. The higher urine volume resulted in significantly lower urinary cystine concentration. To incorporate the effect of both urine $\mathrm{pH}$ and cystine concentration on the solubility of cystine, the ion activity product of cystine was estimated [25]. The ion activity product was lower with intake of the MD and VD, and thus reflected urinary cystine concentration rather than urine $\mathrm{pH}$. To achieve the additional increase in urine output by approximately $1.0 \mathrm{~L} / 24 \mathrm{~h}$ and to support continuous alkalinization in cystinuria, the consumption of beverages such as bicarbonate-rich mineral water and citrus juices is beneficial in the dietary management of patients with cystine nephrolithiasis [47].

A limitation of our study is the relatively small number of participants. As the study was conducted under strictly controlled conditions, a steady state of metabolism can be assumed. A prospective study of patients with cystinuria is warranted to confirm the effects observed on different diets and to evaluate the efficacy of a vegetarian diet in terms of stone activity.

\section{Conclusions}

To our knowledge, this is the first study to evaluate the impact of different diets on the urinary excretion of cystine and cysteine in healthy subjects. The present findings suggest that dietary phosphorus intake, as estimated from urinary phosphate excretion, is a predictor of urinary cystine excretion, while urinary sulfate, a biomarker for the intake of the sulfur-containing amino acids methionine and cystine, is the major determinant of urinary cysteine excretion. Neither cystine nor cysteine excretion was affected by dietary sodium intake, as judged by urinary sodium excretion. A vegetarian diet is particularly suitable for the dietary treatment of cystine stone disease, since the alkaline load from fruits and vegetables may reduce the amount of alkalizing agents required to achieve urine alkalinization at $\mathrm{pH}$ greater than 7.5. Further research is needed to evaluate the effects of different diets on the urinary risk profile and the progression of stone formation as outcome measures in patients with cystinuria.

Author Contributions: Conceptualization, R.S. and A.H.; methodology, R.S., H.B., and A.H.; formal analysis, R.S. and N.B.; investigation, R.S.; data curation, R.S. and N.B.; supervision, R.S. and A.H.; writing—original draft preparation, R.S.; writing—review and editing, R.S., N.B., H.B., and A.H. All authors have read and agreed to the published version of the manuscript.

Funding: This research received no external funding.

Institutional Review Board Statement: The study was conducted in accordance with the Declaration of Helsinki, and the protocol was approved by the Ethics Committee of the Medical Faculty of the University of Bonn (committee's reference number 01889).

Informed Consent Statement: Informed consent was obtained from all subjects involved in the study.

Data Availability Statement: Data is available on request.

Conflicts of Interest: The authors declare no conflict of interest. 


\section{References}

1. Milliner, D.S.; Murphy, M.E. Urolithiasis in pediatric patients. Mayo Clin. Proc. 1993, 68, 241-248. [CrossRef]

2. Lieske, J.C.; Rule, A.D.; Krambeck, A.E.; Williams, J.C.; Bergstralh, E.J.; Mehta, R.A.; Moyer, T.P. Stone composition as a function of age and sex. Clin. J. Am. Soc. Nephrol. 2014, 9, 2141-2146. [CrossRef]

3. Eggermann, T.; Venghaus, A.; Zerres, K. Cystinuria: An inborn cause of urolithiasis. Orphanet J. Rare Dis. 2012, 7, 19. [CrossRef]

4. Edvardsson, V.O.; Goldfarb, D.S.; Lieske, J.C.; Beara-Lasic, L.; Anglani, F.; Milliner, D.S.; Palsson, R. Hereditary causes of kidney stones and chronic kidney disease. Pediatr. Nephrol. 2013, 28, 1923-1942. [CrossRef]

5. Thomas, K.; Wong, K.; Withington, J.; Bultitude, M.; Doherty, A. Cystinuria-A urologist's perspective. Nat. Rev. Urol. 2014, 11, 270-277. [CrossRef]

6. Sahota, A.; Tischfield, J.A.; Goldfarb, D.S.; Ward, M.D.; Hu, L. Cystinuria: Genetic aspects, mouse models, and a new approach to therapy. Urolithiasis 2019, 47, 57-66. [CrossRef] [PubMed]

7. Assimos, D.G.; Leslie, S.W.; Ng, C.; Streem, S.B.; Hart, L.J. The impact of cystinuria on renal function. J. Urol. 2002, 168, 27-30. [CrossRef]

8. Claes, C.J.; Jackson, E. Cystinuria: Mechanisms and management. Pediatr. Nephrol. 2012, 27, 2031-2038. [CrossRef]

9. Hesse, A.; Tiselius, H.G.; Siener, R.; Hoppe, B. Urinary Stones: Diagnosis, Treatment, and Prevention of Recurrence; 3rd revised and enlarged edition; Karger: Basel, Switzerland, 2009.

10. Eisner, B.H.; Goldfarb, D.S.; Baum, M.A.; Langman, C.B.; Curhan, G.C.; Preminger, G.M.; Lieske, J.C.; Pareek, G.; Thomas, K.; Zisman, A.L.; et al. Evaluation and medical management of patients with cystine nephrolithiasis: A consensus statement. J. Endourol. 2020, 34, 1103-1110. [CrossRef] [PubMed]

11. Servais, A.; Thomas, K.; Strologo, L.D.; Sayer, J.A.; Bekri, S.; Bertholet-Thomas, A.; Bultitude, M.; Capolongo, G.; Cerkauskiene, R.; Daudon, M.; et al. on behalf of the Metabolic Nephropathy Workgroup of the European Reference Network for Rare Kidney Diseases (ERKNet) and eUROGEN. Cystinuria: Clinical practice recommendation. Kidney Int. 2020. [CrossRef]

12. Rodman, J.S.; Blackburn, P.; Williams, J.J.; Brown, A.; Pospischil, M.A.; Peterson, C.M. The effect of dietary protein on cystine excretion in patients with cystinuria. Clin. Nephrol. 1984, 22, 273-278.

13. Remer, T.; Manz, F. Estimation of the renal net acid excretion by adults consuming diets containing variable amounts of protein. Am. J. Clin. Nutr. 1994, 59, 1356-1361. [CrossRef] [PubMed]

14. Siener, R.; Struwe, F.; Hesse, A. Effect of L-methionine on the risk of phosphate stone formation. Urology 2016, 98, 39-43. [CrossRef]

15. Jaeger, P.; Portmann, L.; Saunders, A.; Rosenberg, L.E.; Thier, S.O. Anticystinuric effects of glutamine and of dietary sodium restriction. N. Engl. J. Med. 1986, 315, 1120-1123. [CrossRef] [PubMed]

16. Norman, R.W.; Manette, W.A. Dietary restriction of sodium as a means of reducing urinary cystine. J. Urol. 1990, 143, 1193-1195. [CrossRef]

17. Goldfarb, D.S.; Coe, F.L.; Asplin, J.R. Urinary cystine excretion and capacity in patients with cystinuria. Kidney Int. 2006, 69, 1041-1047. [CrossRef]

18. Siener, R.; Hesse, A. Dietary assessment and advice. In Urinary Tract Stone Disease; Rao, P.N., Kavanagh, J.P., Preminger, G.M., Eds.; Springer-Verlag: London, UK, 2011; pp. 687-694.

19. Deutsche Gesellschaft für Ernährung; Österreichische Gesellschaft für Ernährung; Schweizerische Gesellschaft für Ernährungsforschung; Schweizerische Vereinigung für Ernährung (German, Austrian and Swiss Societies of Nutrition). Referenzwerte für die Nährstoffzufuhr (Reference Values for Nutrient Intake), 6th ed.; Deutsche Gesellschaft für Ernährung e.V.: Bonn, Germany, 2020.

20. Holbrook, J.T.; Patterson, K.Y.; Bodner, J.E.; Douglas, L.W.; Veillon, C.; Kelsay, J.L.; Mertz, W.; Smith, J.C. Sodium and potassium intake and balance in adults consuming self-selected diets. Am. J. Clin. Nutr. 1984, 40, 786-793. [CrossRef]

21. Ennis, J.L.; Asplin, J.R. The role of the 24-h urine collection in the management of nephrolithiasis. Int. J. Surg. 2016, 36, 633-637. [CrossRef]

22. Williams, J.C.; Gambaro, G.; Rodgers, A.; Asplin, J.; Bonny, O.; Costa-Bauzá, A.; Ferraro, P.M.; Fogazzi, G.B.; Fuster, D.; Goldfarb, D.S.; et al. Urine and stone analysis for the investigation of the renal stone former: A consensus conference. Urolithiasis 2020. [CrossRef] [PubMed]

23. Siener, R.; Jansen, B.; Watzer, B.; Hesse, A. Effect of n-3 fatty acid supplementation on urinary risk factors for calcium oxalate stone formation. J. Urol. 2011, 185, 719-724. [CrossRef] [PubMed]

24. Birwé, H.; Hesse, A. Determination of cysteine and cystine by HPLC. Fresenius J. Anal. Chem. 1990, 337, 62-63.

25. Tiselius, H.G. Solution chemistry of supersaturation. In Kidney Stones: Medical and Surgical Management; Coe, F.L., Favus, M.J., Pak, C.Y.C., Parks, J.H., Preminger, G.M., Eds.; Lippincott-Raven Publishers: Philadelphia, Pennsylvania, 1996 ; pp. 33-64.

26. Dent, C.E.; Senior, B. Studies on the treatment of cystinuria. Br. J. Urol. 1955, 27, 317-332. [CrossRef]

27. Cupisti, A.; Gallieni, M. Urinary phosphorus excretion. Not what we have believed it to be? Clin. J. Am. Soc. Nephrol. 2018, 13, 973-974. [CrossRef]

28. Morimoto, Y.; Sakuma, M.; Ohta, H.; Suzuki, A.; Matsushita, A.; Umeda, M.; Ishikawa, M.; Taketani, Y.; Takeda, E.; Arai, H. Estimate of dietary phosphorus intake using 24-h urine collection. J. Clin. Biochem. Nutr. 2014, 55, 62-66. [CrossRef] [PubMed]

29. Trautvetter, U.; Ditscheid, B.; Jahreis, G.; Glei, M. Habitual intakes, food sources and excretions of phosphorus and calcium in three German study collectives. Nutrients 2018, 10, 171. [CrossRef] [PubMed] 
30. Cupisti, A.; Kalantar-Zadeh, K. Management of natural and added dietary phosphorus burden in kidney disease. Semin. Nephrol. 2013, 33, 180-190. [CrossRef]

31. Calvo, M.S.; Uribarri, J. Contributions to total phosphorus intake: All sources considered. Semin. Dial. 2013, 26, 54-61. [CrossRef]

32. Malieckal, D.A.; Modersitzki, F.; Mara, K.; Enders, F.T.; Asplin, J.R.; Goldfarb, D.S. Effect of increasing doses of cystine-binding thiol drugs on cystine capacity in patients with cystinuria. Urolithiasis 2019, 47, 549-555. [CrossRef]

33. Yin, J.; Ren, W.; Yang, G.; Duan, J.; Huang, X.; Fang, R.; Li, C.; Li, T.; Yin, Y.; Hou, Y.; et al. L-Cysteine metabolism and its nutritional implications. Mol. Nutr. Food Res. 2016, 60, 134-146. [CrossRef] [PubMed]

34. Peces, R.; Sánchez, L.; Gorostidi, M.; Alvarez, J. Effects of variation in sodium intake on cystinuria. Nephron 1991, 57, 421-423. [CrossRef]

35. Rodriguez, L.M.; Santos, F.; Malaga, S.; Martinez, V. Effect of a low sodium diet on urinary elimination of cystine in cystinuric children. Nephron 1995, 71, 416-418. [CrossRef] [PubMed]

36. Palacin, M.; Borsani, G.; Sebastio, G. The molecular bases of cystinuria and lysinuric protein intolerance. Curr. Opin. Genet. Dev. 2001, 11, 328-335. [CrossRef]

37. Chillaron, J.; Font-Llitjos, M.; Fort, J.; Zorzano, A.; Goldfarb, D.S.; Nunes, V.; Palacin, M. Pathophysiology and treatment of cystinuria. Nat. Rev. Nephrol. 2010, 6, 424-434. [CrossRef]

38. Xu, H.; Zisman, A.L.; Coe, F.L.; Worcester, E.W. Kidney stones: An update on current pharmacological management and future directions. Expert Opin. Pharmacother. 2013, 14, 435-447. [CrossRef]

39. Saravakos, P.; Kokkinou, V.; Giannatos, E. Cystinuria: Current diagnosis and management. Urology 2014, 83, 693-699. [CrossRef]

40. Jung, H.; Andonian, S.; Assimos, D.; Averch, T.; Geavlete, P.; Kohjimoto, Y.; Neisius, A.; Philip, J.; Saita, A.; Shah, H.; et al. Urolithiasis: Evaluation, dietary factors, and medical management: An update of the 2014 SIU-ICUD international consultation on stone disease. World J. Urol. 2017, 35, 1331-1340. [CrossRef]

41. Barbey, F.; Joly, D.; Rieu, P.; Méjean, A.; Daudon, M.; Jungers, P. Medical treatment of cystinuria: Critical reappraisal of long-term results. J. Urol. 2000, 163, 1419-1423. [CrossRef]

42. Ng, C.S.; Streem, S.B. Medical and surgical therapy of the cystine stone patient. Curr. Opin. Urol. 2001, 11, 353-358. [CrossRef] [PubMed]

43. Tiselius, H.G. New horizons in the management of patients with cystinuria. Curr. Opin. Urol. 2010, 20, 169-173. [CrossRef]

44. Türk, C.; Neisius, A.; Petrik, A.; Seitz, C.; Skolarikos, A.; Thomas, K. EAU Guidelines on Urolithiasis; European Association of Urology: Arnhem, The Netherlands, 2000.

45. Prot-Bertoye, C.; Lebbah, S.; Daudon, M.; Tostivint, I.; Jais-Philippe, J.; Louët, A.L.; Pontoizeau, C.; Pontoizeau, C.; Bataille, P.; Bridoux, F.; et al. Adverse events associated with currently used medical treatments for cystinuria and treatment goals: Results from a series of 442 patients in France. BJU Int. 2019, 124, 849-861. [CrossRef] [PubMed]

46. Dent, C.E.; Friedman, M.; Green, H.; Watson, L.C.A. Treatment of cystinuria. Br. Med. J. 1965, 1, 403-408. [CrossRef] [PubMed]

47. Siener, R. Can the manipulation of urinary $\mathrm{pH}$ by beverages assist with the prevention of stone recurrence? Urolithiasis 2016, 44, 51-56. [CrossRef] [PubMed] 